\title{
Monoclonal opsonic mouse antibodies specific for streptococcal IgG Fc-receptor
}

\author{
M. SVENSSON, P. CHRISTENSEN and D. SCHALÉN
}

Department of Medical Microbiology, University of Lund, Lund, Sweden

Summary. Spleen cells from mice immunised with group-A type-M15 streptococci and boosted with purified IgG Fc-receptor ( $F c R$ ) from this type were fused with Sp 2/0 mouse myeloma cells. The resulting hybridomas were screened by ELISA for antibody production. Two IgM-secreting cell lines were selected. The monoclonal antibodies and ascites fluids inhibited the binding of ${ }^{125} \mathrm{I}$-labelled human IgG and IgG Fc-fragments to group-A type-M15 streptococci. The monoclonal antibodies also displaced purified FcR towards the anode in electrophoresis. They opsonised group-A type M-15 streptococci for phagocytosis by human granulocytes in the presence of fresh human serum. It was concluded that FcR is important for group-A streptococcal virulence.

\section{Introduction}

Many group-A, $-\mathrm{C}$ and $-\mathrm{G}$ streptococci have receptors for the Fc part of human IgG (Christensen et al., 1976) as well as for that of IgG from several other mammalian species (Myhre and Kronvall, 1977). The streptococcal IgG Fc-receptors (FcRs) react with all four human IgG subclasses (Christensen and Oxelius, 1974), whereas staphylococcal protein A binds only IgG 1, 2 and 4 (Kronvall and Williams, 1969). Binding studies with $\mathrm{IgG}$ from different mammalian species have revealed a heterogeneity amongst FcRs (Myhre and Kronvall, 1977). Furthermore, the different molecular weights of the FcRs studied so far, 29500 for group A type M15 (Grubb et al., 1982), 60000-70 000 for group C (Christensen and Holm, 1976; Reis et al., 1984a) and 30000 for group G (Björck and Kronvall, 1984) suggest chemical differences. The FcRs have been distinguished from other streptococcal components, including M protein, $\mathrm{T}$ protein, lipoteichoic acid, peptidoglycan and the group-specific carbohydrate (Christensen et al., 1979; Schalén et al., 1980).

In-vivo (Burova et al., 1980) and in-vitro studies (Schalén et al., 1981; Burova et al., 1982) have demonstrated the importance of the FcRs for virulence. This may be explained by their capacity to block antibody-mediated complement-dependent cell lysis (Burova et al., 1982). However, many questions remain concerning the pathogenetic role of the FcRs. For example, it is not known whether

Received 17 Oct. 1985; accepted 19 Mar. 1986. antibodies directed against the FcRs are protective, because the antigenicity of the receptors has been subjected to only few investigations. A previous study suggested that antibodies to FcRs might occur in rabbit antisera raised against certain mouse-passaged group-A strains (Burova et al., 1980). However, the fact that the FcRs react with the Fc part of IgG raises natural obstacles to the study of their antigenicity. Thus it might be difficult to establish whether a reaction with an antibody is due to a "true" antigen-antibody interaction, or to $\mathrm{Fc}$ reactivity. The use of $\mathrm{IgG}$ $F\left(\mathrm{ab}^{\prime}\right)_{2}$ fragments does not avoid this dilemma, because such fragments may also bind to streptococci, irrespective of the specificity of the antibodycombining sites (Schalén et al., 1983). Moreover, the FcRs may trigger the production of anti-IgG during immunisation with streptococci and the anti-IgG may react with IgG bound to FcRs (Lebrun et al., 1982; Burova et al., 1985).

Taking advantage of the fact that the FcRs do not bind normal chicken immunoglobulins, Reis $e t$ al. (1984b) used chickens for production of antibodies to group-C streptococcal FcRs. Similarly, mouse immunoglobulins do not react with groupA streptococcal FcRs (Myhre and Kronvall, 1977). Mouse hybridoma antibodies would therefore seem to overcome all theoretical difficulties mentioned above, since properly prepared monoclonal antibodies should not contain anti-IgG or antibodies to streptococcal components other than the FcRs. We have, therefore, studied the possibility of producing mouse hybridoma antibodies to the group-A streptococcal FcRs. 


\section{Materials and methods}

\section{Streptococcal extract and purified FcR}

Alkaline extract and purified FcR were prepared from group-A type M15 streptococci (strain EF 1949 referred to below as test streptococci) as previously described (Christensen et al., 1979: Grubb et al., 1982).

\section{Sera}

Normal mouse serum was a pool from 20 unimmunised mice. Class determination of mouse hybridoma antibodies was performed by gel double diffusion against rabbit antisera to mouse IgG and IgM (Bio-Yeda, Rehovet. Israel). Rabbit antiserum to group-A type-M15 streptococci was raised as previously described (Christensen et al., 1979).

\section{Cell line}

Non-secreting Sp 2/0 mouse myeloma cells (kindly supplied by $\operatorname{Dr}$ A. Lundblad, Lund, Sweden) were treated with 8-azaguanine to inhibit growth of revertant cells (Shulman et al.. 1978). The cells were cultured in CM-medium, i.e., Dulbecco's modified Eagle medium containing fetal calf serum (heated at $56 \mathrm{C}$ for $30 \mathrm{~min}$ ) $17 \% \mathrm{v} / \mathrm{v} 100 \times$ non-essential amino acids $1 \% \mathrm{v} / \mathrm{v} 4 \mathrm{~mm}$ glutamine, $0.6 \mathrm{~mm}$ pyruvate, HEPES $0.2 \% \mathrm{v} / \mathrm{v}$, gentamicin $50 \mu \mathrm{g} / \mathrm{ml}$ (Flow, Irvine, Ayrshire), $5 \mathrm{~mm}$ oxaloacetic acid (Merck, Darmstedt, W. Germany) and insulin (Kabi-Vitrum, Stockholm, Sweden) 0.02 IE/ml. The cell cultures were maintained in a humidified incubator at $37 \mathrm{C}$ in an atmosphere of $\mathrm{CO}_{2} 7 \%$ in air.

\section{Immunisation of mice}

For vaccine production, the test streptococcus was cultured overnight in Todd-Hewitt broth, washed in phosphate-buffered saline (PBS; $0.12 \mathrm{M} \mathrm{NaCl}, 0.03 \mathrm{M}$ sodium phosphate, $p \mathrm{H} 7.2$ ), treated with formalin $0.3 \% \mathrm{v} / \mathrm{v}$ in PBS for $30 \mathrm{~min}$ and resuspended in PBS to an optical density (OD) of 1.0 at $540 \mathrm{~nm}$. The first immunisation was performed with a mixture of equal volumes of bacteria and Freund's complete adjuvant (Difco). Balb/c mice (Bomholtsgaard, Ry, Denmark), 7-12 weeks old, were given a total volume of $0.1 \mathrm{ml}$ subcutaneously at the neck and at the base of the tail. This procedure was repeated every third week during 15 months, except that Freund's incomplete adjuvant (Difco) was used. Four days before cell fusion (see below), the mice were given booster injections of $0.1 \mathrm{ml}(0.2 \mathrm{mg})$ purified $\mathrm{IgG}$ Fcreceptors intraperitoneally.

\section{Cell fusion}

The method of Galfre et al. (1977) was used with the following minor modifications. The spleen was removed from the immunised mouse and placed on a stainless steel wire mesh, moistened with $10 \mathrm{ml}$ of serum-free CM medium and gently pressed with a spoon to liberate the cells. The cells were washed three times with serum-free $\mathrm{CM}$ by centrifugation for $7 \mathrm{~min}$ at $150 \mathrm{~g}$. Sp $2 / 0$ cells were cultured and harvested in the exponential phase by centrifugation for $30 \mathrm{~min}$ at $400 \mathrm{~g}$, washed three times and re-suspended in serum-free $\mathrm{CM}$ medium.

The Sp 2/0 mouse myeloma cells $\left(10^{7}\right)$ were mixed with $10^{8}$ spleen cells; the mixture was centrifuged at $150 \mathrm{~g}$ and the cells fused by means of PEG 1500 (Kebo Grave, Arlöv, Sweden) $50 \% \mathrm{w} / \mathrm{v}$ diluted in serum-free CM. PEG $(1 \mathrm{ml})$ and the pellet from the cell mixture were placed in a $37 \mathrm{C}$ water bath. When a temperature of $37^{\circ} \mathrm{C}$ had been reached in both tubes, the PEG 1500 was added drop-by-drop to the cells over a period of $1 \mathrm{~min}$. The mixture was then rotated for $1 \mathrm{~min}$ after which serumfree $\mathrm{CM}$ at $37 \mathrm{C}$ was added stepwise over $5 \mathrm{~min}$ to a total volume of $15 \mathrm{ml}$. The tube was centrifuged at $150 \mathrm{~g}$ for $7 \mathrm{~min}$ and the pellet was resuspended to a cell concentration of $10^{6} / \mathrm{ml}$ in the medium remaining after the initial harvest of the Sp 2,0 cells, supplemented with $100 \mathrm{~mm}$ hypoxanthine, $0.4 \mu \mathrm{m}$ aminopterine and $16 \mu \mathrm{m}$ thymidine (CM/HAT). The suspension was dispensed into five 96well plates (NUNC. Roskilde, Denmark; $100 \mu$ l of cells/ well) that had been seeded $24 \mathrm{~h}$ previously with 3000 mouse macrophages/well to provide feeder-cells. After incubation for 1 week the culture medium was removed with a pasteur pipette and $200 \mu \mathrm{l}$ of $\mathrm{CM} / \mathrm{HAT}$ was added to each well. The wells were tested 3 days later for antibody production as described below.

\section{Cloning procedure}

Thymus cells were harvested from 4-week-old Balb/c mice as described above for spleen cells and suspended to a concentration of $3 \times 10^{6} / \mathrm{ml}$ in CM/HAT.

Wells that gave positive results in the ELISA tests (see below) with crude alkaline extract and purified FcR were used for recloning. After counting the cells, the suspension to be cloned was diluted in the suspension of thymus cells in four steps to give a final concentration of 1 cell/ well in $200 \mu \mathrm{l}$ of $\mathrm{CM} / \mathrm{HAT}$. Each of the four dilutions was seeded into 16 wells to concentrations of $200 \mu \mathrm{l}$ per well. After incubation for 1-2 weeks the wells were inspected for growth with a microtitration-plate mirror and supernates from growing clones were tested by ELISA. Positive clones were again cloned as above. Finally, two single-cell clones that gave positive results in ELISA were propagated stepwise for large scale culture (see Results).

\section{Production of ascites-fluid hybridoma-antibodies in mice}

$\mathrm{Balb} / \mathrm{c}$ mice, 8 weeks old, were given an intraperitoneal injection of $0.5 \mathrm{ml}$ of 2,6,10,14-tetramethylpentadecan (Pristan; Sigma). Between 1 and 5 weeks later, $2.5 \times 10^{6}$ antibody-secreting hybrids were introduced intraperitoneally. Ascites fluid was harvested after 1 week, centrifuged to remove the cells and stored at $-20^{\circ} \mathrm{C}$ until use. 
For antibody purification, $5 \mathrm{ml}$ of ascites fluid was separated on a Sephadex G200 column (Pharmacia Fine Chemicals, Uppsala, Sweden) equilibrated with PBS. Pooled fractions were concentrated by precipitation with saturated $\left(\mathrm{NH}_{4}\right)_{2} \mathrm{SO}_{4}$ followed by redissolving in $5 \mathrm{ml}$ of PBS and dialysis against PBS. Selected pooled fractions were absorbed on a protein A-Sepharose $4 B$ column to remove IgG.

\section{Hybridoma antibodies against group-B streptococ- cal $(G B S)$ R-protein}

In-vitro cell culture and production of hybridomaascites IgM antibodies against GBS R-protein was performed essentially as described for hybridoma antibodies to $\mathrm{FcR}$. After production of ascites, the antibodies were enriched on Sephadex G200 as described above.

\section{ELISA for screening of cell cultures for anti-FcR antibodies}

NUNC-immunoplates were coated with an alkaline extract of streptococci or purified FcR $(0.5 \mu \mathrm{g} / \mathrm{ml})$. To block uncoated sites on the plate, gelatin (Merck) $1 \%$ $w / v$ in PBS was added. Between each step plates were washed with PBS containing Tween 20 (Kebo Grave) $0.05 \% \mathrm{v} / \mathrm{v}$. The plates were stored at $-20^{\circ} \mathrm{C}$ in the blocking solution (PBS/gelatin) until used.

To test for antibody production, $75 \mu$ l of supernate from each well of the fusion plates was added to the ELISA plate which was then gently shaken at room temperature for $1 \mathrm{~h}$. After washing, $100 \mu \mathrm{l}$ of horseradish peroxidase-labelled swine $\mathrm{F}\left(\mathrm{ab} \mathrm{b}^{\prime}\right)_{2}$ IgG specific for mouse Ig (EY, San Mateo, CA, USA) diluted 1 in 200 was added and the plates were agitated for a further $1 \mathrm{~h}$. After four washes, $100 \mu \mathrm{l}(40 \mathrm{mg})$ of $o$-phenylene-diaminedihydrochloride (FLUKA, Buchs, Switzerland) dissolved in $34 \mathrm{~mm}$ citric acid, $66.7 \mathrm{~mm} \mathrm{Na}{ }_{2} \mathrm{HPO}_{4}$ and $\mathrm{H}_{2} \mathrm{O}_{2}$ $20 \mathrm{ml} / 100 \mathrm{ml}$ was added. The colour reaction was monitored at $450 \mathrm{~nm}$ after $30 \mathrm{~min}$, with a Titertek Multiscan (Flow). The background did not exceed $0 \cdot 1$ OD units whereas positive wells gave results between 0.4 and 1.2 .

\section{Electromigration assay}

This assay was performed essentially as previously described (Christensen et al., 1979). In brief, purified FcR, $0.1 \mathrm{mg} / \mathrm{ml}$, was mixed with equal volumes of hybridoma antibodies and subjected to agar electrophoresis with a voltage of $20 \mathrm{~V} / \mathrm{cm}$ for $1 \mathrm{~h}$. A channel was then cut in the direction of the current and filled with horseradish peroxidase-labelled purified IgG1 myeloma protein $1.5 \mathrm{mg} /$ ml (kindly supplied by Dr A. Grubb, Malmö, Sweden). After diffusion overnight, the precipitate was stained by adding 3-amino-9-ethyl-carbazole as described by Löfberg and Grubb (1979).

\section{Radiobinding assay}

Commercial human IgG (Kabi-Vitrum) or purified
IgG Fc-fragments (kindly supplied by Dr F. Nardella, Seattle, USA) were labelled with ${ }^{125}$ I as described by McConahey and Dixon (1966). Test streptococci were cultured overnight in Todd-Hewitt broth, washed once in PBS and resuspended in PBS to a concentration of $10^{\circ}$ bacteria/ml. In plastic tubes, $1 \mathrm{ml}$ of PBS containing Tween $200 \cdot 1 \%$ (PBS/T) was mixed with $2 \mathrm{ml}$ of supernate from an antibody-producing clone, $200 \mu \mathrm{l}$ of fractions from the purification ascites antibody, or $200 \mu \mathrm{l}$ of ascitic fluid or normal mouse serum, and $5 \times 10^{7}$ bacteria were added and incubated for $1 \mathrm{~h}$ at $37^{\circ} \mathrm{C}$. Before centrifugation at $3000 \mathrm{~g}$ for $15 \mathrm{~min}, 50 \mu \mathrm{l}$ of sheep red blood cells $10 \% \mathrm{v} / \mathrm{v}$ were added to visualise the sediment. The supernate was then removed and the pellet resuspended in $1 \mathrm{ml}$ of PBS/T. To each test tube was then added $0.5 \mu \mathrm{g}$ of ${ }^{125}$ labelled human IgG or $0.25 \mu \mathrm{g}{ }^{125} \mathrm{I}$-labelled IgG Fc and the tubes were left at $22^{\circ} \mathrm{C}$ for $30 \mathrm{~min} ; 2 \mathrm{ml}$ of PBS/T was added and the tubes centrifuged at $3000 \mathrm{~g}$. After aspiration of the supernate, the radioactivity remaining in the tube was counted in a LKB Wallac 1260 Multigamma (LKB, Stockholm, Sweden). In the test conditions used, in the absence of inhibitor substances the test strain bound $20-30 \%$ of the radioactive IgG added.

The results were expressed as percentage inhibition, calculated from the formula $100 \times \mathrm{Ba}-\mathrm{Bp} / \mathrm{Ba}$, where $\mathrm{Ba}$ is the binding of radioactivity in the absence of the test preparation and $\mathrm{Bp}$ is the binding in the presence of the test preparation. The mean of determinations in triplicate was calculated.

\section{Opsonophagocytic killing test}

A modification of the microtitration opsonophagocytic assay described by Fischer et al. (1978) was used to prepare human granulocytes (PMN). Ten $\mathrm{ml}$ of heparinised blood was mixed with $3 \mathrm{ml}$ of Dextran 250 (Pharmacia) $6 \%$ in saline and the glass tubes were left at an angle of $45^{\circ}$ for $45 \mathrm{~min}$ at room temperature. After centrifugation at $90 \mathrm{~g}$ the supernate was discarded and the pellet was suspended in a mixture of homologous plasma $2 \mathrm{ml}$ and sterile filtered $0.9 \%$ ammonium chloride $2 \mathrm{ml}$ to lyse remaining erythrocytes. After incubation for $6 \mathrm{~min}$, $6 \mathrm{ml}$ of PBS was added. The cells were harvested by centrifugation as above followed by washing in PBS and in RPMI medium (Flow) without HEPES or glutamine but containing bicarbonate and sterile gelatin $0.1 \%$ (RPMIgel). Finally, the cells were suspended in $2 \mathrm{ml}$ of RPMIgel to $c .10^{7} / \mathrm{ml}$. The cell viability was $>99 \%$ as determined by trypan blue exclusion.

The test was performed in sterile plastic microtitration plates with U-shaped wells (Titertek: Flow). The following reagents were added unless otherwise stated: (a) $25 \mu \mathrm{l}$ of heat-inactivated rabbit pre-immune or immune serum, or $25 \mu \mathrm{l}$ of the test preparation; (b) $50 \mu \mathrm{l}$ of fresh normal human serum diluted 1 in 10 in RPMI-gel; (c) $25 \mu$ l of PMN suspension; and (d) $25 \mu \mathrm{l}$ of streptococcal suspensions equivalent to $10^{7} \mathrm{cfu} \mathrm{ml}$ of RPMI-gel. Standardised suspensions of exponential-phase streptococci were preserved in small volumes at $-80^{\circ} \mathrm{C}$ in Todd-Hewitt broth supplemented with heat-inactivated fetal calf serum $20 \%$ 
(Burova et al., 1980). The plastic plates were sealed and incubated at $37 \mathrm{C}$ for $2 \mathrm{~h}$ with gentle shaking to prevent sedimentation of the cells. The plates were then cooled on ice and from each well a $10-\mu l$ sample was removed and diluted in bovine serum albumin $0.1 \%$ in distilled water to lyse the PMN. Ten-fold dilutions were plated on blood agar and the colonies of bacteria counted after incubation overnight at $37 \mathrm{C}$.

The results were expressed as the bactericidal index (BI) calculated from the formula: count (cfu) with normal serum/count (cfu) with antiserum.

\section{Results}

Preparation of $\operatorname{IgM}$ hybridoma antibodies with specificity for $F C R$

After incubation of the fusion plates for 10 days, growth was seen in 433 of the 480 wells and 26 $(6 \%)$ of the wells with growth produced antibodies against the purified FcR. However, after cloning and recloning, most derivatives of the originally positive wells lost their capacity to secrete antibodies against the FCR and only 5 out of 26 of the derivatives of the positive wells remained positive at the single-cell clone step. Two cell clones, 2F9G10B3 and 2F9G10B4 showed strong antibody production and were selected for ascites production in Pristan-primed mice.

Sephadex G200 fractions of the ascites fluids were tested for capacity to inhibit the binding of 125 I-labelled IgG to the test streptococci. The fractions corresponding to the initial peak produced $70 \%$ inhibition (fig. 1) and these fractions were pooled. The pools obtained from each clone were tested in double diffusion in gel tests against antisera specific for mouse IgG and IgM. The pooled preparations were precipitated only by anti-IgM and are referred to below as the IgM pools. In agarose-gel electrophoresis, each of the two pools showed a distinct band in the $\gamma$-region as well as a band with an electrophoretic mobility corresponding to $x_{2}$-macroglobulin.

Supernates from in-vitro cultures of the two clones were also tested by double diffusion in gel against the class-specific anti-mouse Ig sera. The supernates were precipitated only by anti-IgM. Controls with the CM culture medium and the supernate from a culture of $\mathrm{Sp} 2 / 0$ cells were negative.

Inhibition of binding of radiolabelled human $\operatorname{Ig} G$ and $\operatorname{IgG-Fc-fragments~to~the~test~streptococci~by~anti-~}$ $F \cdot R$ hybridoma antibodies

The supernates from in-vitro cultures of both

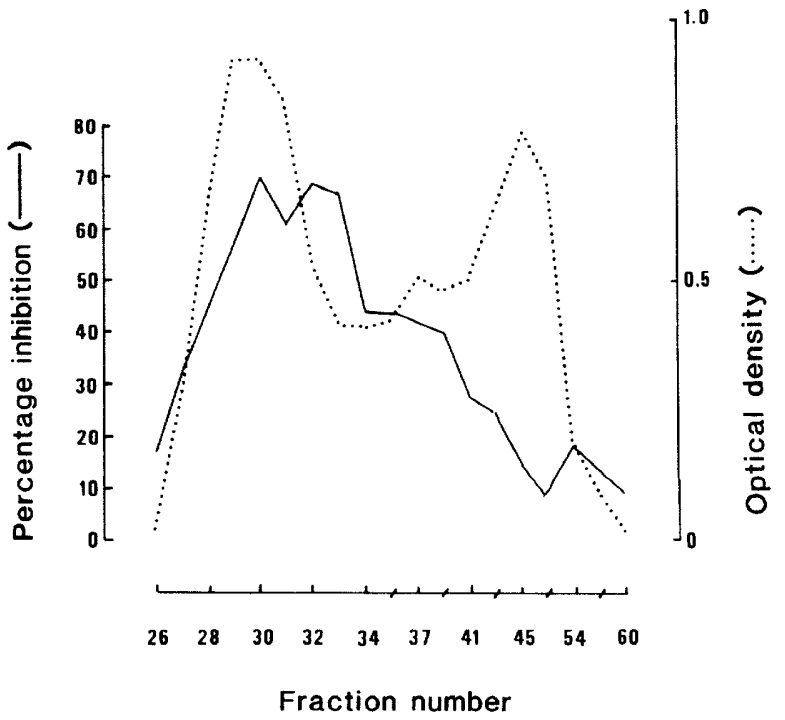

Fig. 1. The capacity of Sephadex G200 fractions obtained by chromatography of ascites fluid of clone 2F9G10B3 to inhibit the binding of radiolabelled human IgG to group-A type-M15 streptococci.

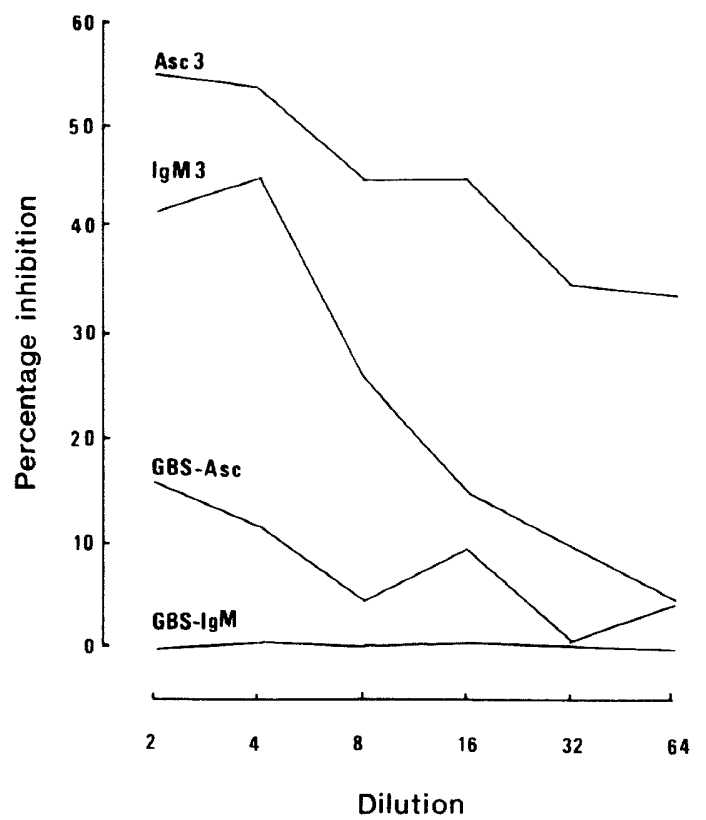

Fig. 2. The capacities of various preparations to inhibit the binding of $125 \mathrm{I}$-labelled human IgG to group-A type-M15 streptococci. Asc 3 - clone 2F9G10B3 ascites fluid; IgM3-IgM pool obtained by Sephadex G200 chromatography of Asc 3; GBS-Asc-ascites fluid from an anti-GBS R-protein clone; GBS-IgM-IgM pool obtained by Sephadex G200 chromatography of GBS-Asc.

clones were tested for capacity to inhibit the binding of ${ }^{125}$ I-labelled human IgG to intact test streptococci. When tested undiluted, both supernates gave $60-70 \%$ inhibition. In contrast, the super- 
nates from the in-vitro culture of the anti-GBS hybridoma antibody-producing cells and the CM medium itself showed no inhibitory capacity.

Ascites fluids, IgM pools and protein Aabsorbed IgM pools obtained from the three cell lines gave similar results (fig. 2). Normal mouse serum was not inhibitory.

Finally, the IgM pools from the respective ascites fluids were tested for inhibition of binding of ${ }^{125} \mathrm{I}$-labelled purified human IgG Fc-fragments to the streptococci. The results corresponded closely to the findings obtained with radiolabelled intact human IgG.

\section{Immunochemical demonstration of the reaction between $F c R$ and anti-FcR hybridoma antibodies}

Both anti-FcR IgM pools displaced the precipitate between FcR and IgG1 towards the anode. No such effect was obtained with the anti-GBS-R-protein ascites fluid. Fig. 3 shows the result obtained with clone 2F9G10B3 IgM.

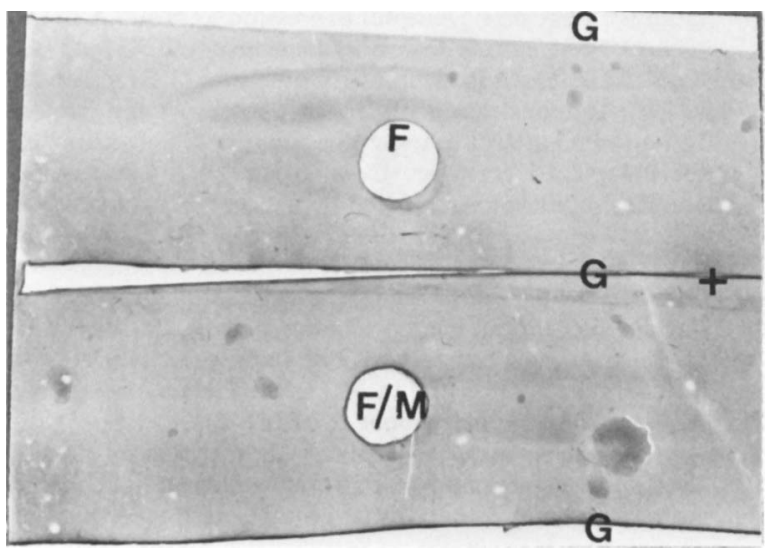

Fig. 3. Electromigration assay with purified IgG Fc-receptor from group-A type-M15 streptococci (labelled F) and IgM ascites pool from clone 2F9G10B3 (labelled $\mathrm{M}$ ). The IgG Fcreceptor was mixed with equal volumes of Asc 3 and subjected to electrophoresis followed by diffusion in gel against horseradish peroxidase-labelled purified IgG1 myeloma (labelled $G$ ) applied in a channel cut in the agar along the original direction of the current; + indicates the anode.

Opsonisation of test streptococci by anti-FcR hybridoma antibodies

The IgM pools from the two clones and antiGBS R-protein were tested at concentations from 0.1 to $0.5 \mathrm{mg} / \mathrm{ml}$ for their capacity to opsonise the test streptococci. The two monoclonal antibodies to FcR gave BIs of 16-24 in repeated experiments, whereas the anti-GBS antibody was without effect. For comparison, rabbit anti-M 15 serum at a dilution of 1 in 10 gave a $\mathrm{BI}$ of 12 .

\section{Discussion}

The results of these studies showed that it was possible to produce mouse monoclonal antibodies specific for the group-A type-M15 streptococcal FcR. The specificity of the antibodies produced by clones 2F9G10B3 and 2F9G10B4 for purified FcR was demonstrated by the capacity of the various preparations to inhibit the binding of radiolabelled IgG and IgG Fc-fragments to the streptococci.

Gel diffusion tests and inhibition tests with the Sephadex G200 fractions demonstrated that the anti-FcR antibodies belonged to the IgM class. The capacity of the IgM pools to inhibit binding of IgG or IgG Fc to streptococci was not affected by absorption on protein A-Sepharose 4B. Further purification to remove a contaminant presumed to be $a_{2}$-macroglobulin was not performed, because pilot experiments showed that it was essential to maintain the monoclonal IgM in solution. However, the failure of monoclonal IgM anti-GBS Rprotein and pooled normal mouse serum to inhibit the binding of IgG to the streptococci excluded the possibility that the reactivity with the FcR could be ascribed to the contaminant. Finally, the displacement of the precipitation line between the FcR and IgG1 myeloma towards the anode after addition of the anti-FcR monoclonal antibodies was similar to that obtained by adding IgG Fc-fragments, as previously described (Christensen et al., 1979), thus providing further evidence for antibody activity directed against the FcR.

The anti-FcR antibodies opsonised streptococci for phagocytosis by human granulocytes in the presence of fresh human serum. Though experiments are in progress to study the details of the opsonisation process, the present reults suggest that the FcR represents a virulence factor. Both we (Burova et al., 1980) and Reis et al. (1984c) found increased FcR activity after repeated mouse passage of certain group-A streptococci, a procedure commonly used to enhance antiphagocytic activity (Lancefield, 1954). Conceivably, the anti-phagocytic activity of the FcRs might be explained at least partly by the finding that the receptors can block IgG-mediated cell lysis (Burova et al., 1982).

We are grateful to Miss Britt-Marie Fredlund for excellent technical assistance. 


\section{REFERENCES}

Björck L. Kronvall G 1984 Purification and some properties of streptococcal protein G. a novel IgG-binding reagent. Journal of Immunology 133:969-974.

Burova L A et al. 1980 Changes in virulence, $M$ protein and IgG Fc-receptor activity in a type 12 group A streptococcal strain during mouse-passages. Acta Pathologica Microbiologica Scundinavica Section B 88:199-205.

Burova L A et al. 1982 Streptococcal IgG Fc-receptor as a virulence factor. In: Holm S E and Christensen P: Basic concepts of streptococci and streptococcal diseases. Reedbooks Ltd. Fox Lane North. Chertsey. Surrey. England. pp 205 206.

Burova L A et al. 1985 Anti-immunoglobulins in experimental streptococcal immunization: relation to bacterial growth conditions and Fc-receptors. Acta Pathologica Microhiologica Immunologica Scandinavica Section C 93:19-23.

Christensen P. Grubb A. Grubb R. Samuelsson G. Schalén C. Svensson M L 1979 Demonstration of the non-identity between the $\mathrm{Fc}$ receptor for human $\mathrm{lgG}$ from group $A$ streptococci type 15 and $M$ protein peptidoglycan and the group specific carbohydrate. Acta Pathologica Microhiologica Scandinarica Section C 87:257 261.

Christensen P. Holm S E 1976 Purification of immunoglobulin G Fc-reactive factor from Sireptococcus azgazardah. Acta Pathologica Microbiologica Scandinavica Section C 84:196 202.

Christensen P. Johansson B G. Kronvall G 1976 Interaction of streptococci with the Fc-fragment of IgG. Acta Pathologica Microhiologica Scandinavica Section C 84:73-76.

Christensen P. Oxelius V A 1974 Quantitation of the uptake of human IgG by some streptococci groups A, B. C and G. Acra Pathologica Microhiologica Scandinarica Section B 82:475.483.

Fischer G W. Lowell G H. Crumrine M H. Bass J W 1978 Demonstration of opsonic activity and in vivo protection against group B streptococci type III by Streptococcus pheumomice type 14 anti-sera. Journal of Experimental Medicine 148:776 786

Galfre G. Howe S C. Milstein C. Butcher G W, Howard J C 1977 Antibodies to major histocompatibility antigens produced by hybrid cellmis. Nature 266:550-552.

Grubb A. Grubb R. Christensen P. Schalén C 1982 Isolation and some properties of an IgG Fc-binding protein from group A streptococci type 15. International Archives of Allergy and Applied Immunology 67:369-376.

Kronvall G. Williams R C 1969 Differences in anti-protein A activity among IgG subgroups. Journal of Immunology' 103: 828.833.

Lancefield R C 1954 Cellular constituents of group A streptococci concerned in antigenecity and virulence. In: McCarty
$M$ (ed) Streptococcal infections. Columbia University Press, New York, pp 3-18.

Lebrun L. Pillot J. Grangeot-Keros L 1982 Significance of antiIgG antibodies obtained by immunization of rabbits with some streptococcal strains. Annales of Immunologie (Institut Pasteur) 133C:45- 56.

Löfberg H, Grubb A 1979 Quantitation of $\gamma$-trace in human biological fluids: indication for production in the central nervous system. Scandinavian Journal of Clinical Laboratory Investigation 39:619.626.

McConahey P J, Dixon F J 1966 A method of trace iodination of proteins for immunologic studies. International Archives of Allergy and Applied Immunology 29:185 -189.

Myhre E B, Kronvall G 1977 Heterogeneity of nonimmune immunoglobulin in $\mathrm{Fc}$ reactivity among gram-positive cocci: description of three major types of receptors for human immunoglobulin G. Infection and Immunity 17:475 482

Reis K J, Ayoub E M. Boyle M D P 1984a Streptococcal Fc receptors. I. Isolation and partial characterization of the receptor from a group C streptococcus. II. Comparison of the reactivity of a receptor from a group $C$ streptococcus with staphylococcal protein A. Journal of Immunology 132 : 3091-3097 and 3098-3102.

Reis K J. Boyle M D P. Ayoub E M 1984b Identification of distinct Fc-receptor molecules on streptococci and staphylococci. Journal of Clinical and Laboratory Immunology 13: $75-80$

Reis K J, Yarnall M, Ayoub E M, Boyle M D P 1984c Effect of mouse passage on Fc receptor expression by group A streptococci. Scandinavian Journal of Immunology 20:433-439.

Schalén C. Christensen P. Grubb A, Samuelsson G, Svensson M L 1980 Demonstration of separate receptors for human IgA and IgG in group A streptococci type 4. Separation of the solubilized receptors from group- and type-specific antigens, lipoteichoic acid and peptidoglycan. Acta Pathologica Microbologic'a Scandinavica Section C. 88:77-82.

Schalén C, Burova L A, Christensen P, Grubb R, Samuelsson G. Svensson M L 1981 IgG F(ab') ${ }_{2}$ of rabbit anti-M sera but not the unfractionated sera are bactericidal for some group A streptococci with IgG Fc-receptor activity: opsonic effects ascribable to anti-IgG. Acta Pathologica Microbiologica Scandinavica Sucrion C 89:247 252.

Schalèn C, Zätterström U, Svensson M L, Christensen P 1983 Binding of aggregated IgG Fab-fragments and light chains to some group $\mathrm{A}$, group $\mathrm{C}$ and group $\mathrm{G}$ streptococci. Acta Pathologica Microbiologica Scandinavica Section B 91:2733.

Shulman M. Wilde C D. Köhler G 1978 A better cell line for making hybridomas secreting specific antibodies. Nature 276:269-210. 